\title{
Kritik Nalar Integrasi Keilmuan di PTKIN: Mengusung Keilmuan Tabot Dan Domestifikasi Studi Keislaman Berwawasan Kebangsaan
}

\author{
Moch Iqbal \\ Institut Agama Islam Negeri Bengkulu \\ moch_iqbal@iainbengkulu.ac.id
}

\begin{abstract}
This paper examines the scientific design that combines Islam with a national perspective, which the author calls the Tabot's scientific. Tabot's scientific design is Islam juxtaposed with local wisdom, to produce a wasathiyah (moderate) Islam. So far, the scientific design at PTKIN only reinforces the scientific dichotomy between science and religion. Such as the science of Spider Web, Tree of Science, Twin Tower and others, all carry the integration of religion and science. Islam itself does not recognize this scientific separation. Using library research (literature study), which is a method that is carried out by collecting data and information from books and writings that are related to the research object which is discussed descriptively-analytic through philosophical studies with a qualitative-rationalistic approach. The results of this study are: first, religion and national locality are like two sides of a coin that cannot be separated. Religion does not exist in a cultural vacuum. Rather, religion always includes two inseparable but distinguishable entities, namely normativity and historicity. Second, it is necessary to ground (domestication), downstream science, both religion and science technology according to the needs of the Indonesian people. So far, the science on campus has been more on the ceiling, in the ivory tower rather than manifesting in beneficial social and technological attitudes. Indonesian scientists are more expert in discourse rather than manifesting in praxis and works.
\end{abstract}

Keywords: Criticism, Science, Tabot, Integration, Domestification.

\begin{abstract}
Abstrak
Paper ini mengkaji tentang desain keilmuan yang menggabungkan antara keislaman berwawasan kebangsaan, yang keilmuan oleh penulis disebut keilmuan Tabot. Desain keilmuan Tabot yaitu Islam yang disandingkan dengan kearifan lokal, untuk menghasilkan islam yang wasathiyah (moderat). Selama ini desain keilmuan di PTKIN hanya mempertegas adanya dikotomi keilmuan, antara sain dan agama. Seperti keilmuan Spider Web, Pohon Ilmu, Twin Tower dan yang lainnya, semua mengusung integrasi agama dan sain. Islam sendiri tidak mengenal pemisahan keilmuan tersebut. Menggunakan library research (studi pustaka), yaitu yaitu metode yang dilakukan dengan cara mengumpulkan data-data dan informasi dari buku-buku serta tulisan-tulisan yang ada hubungannya dengan objek penelitian yang dibahas secara deskriptif-analitik melalui kajian secara filosofis dengan pendekatan kualitatif-rasionalitik. Hasil kajian ini adalah: pertama, agama dan lokalitas kebangsaan seperti dua sisi keping mata uang yang tidak bisa dipisahkan. Agama hadir tidak dalam ruang hampa budaya. Melainkan agama selalu mencakup dua entitas yang tidak dapat dipisahkan tetapi dapat dibedakan, yaitu normativitas dan historitas. Kedua, diperlukan pembumian (domestifikasi), hilirisasi ilmu, baik agama maupun ilmu pengetahuan teknologi sesuai dengan kebutuhan masyarakat Indonesia. Keilmuan di kampus selama ini lebih banyak di langit-langit, di menara gading ketimbang mewujud dalam prilaku sosial dan teknologi yang kaya manfaat. Para ilmuan tanah air lebih ahli berwacana ketimbang mewujud dalam praksis dan karya.
\end{abstract}

Kata Kunci: Keilmuan, Tabot, Integrasi, Domestifikasi 


\section{Pendahuluan}

Pada masa kekhalifahan Bani Abbas, tepatnya tahun $215 \mathrm{H} / 830 \mathrm{M}$ atau abad ke 9, peradaban Islam sudah bisa membuat teropong bintang dengan peralatan yang lengkap di kota Yundhisyapur Iran, sebagai perlengkapan sarana rumah sakit dan sekolah tinggi ilmu pengetahuan. Kemampuan ini adalah pencapaian yang sangat spektakuler pada jamanya. Bidang bidang sain dan teknologi lainnya juga mengalami kemajuan yang sangat pesat, seperti kedokteran matematika dan astronomi. Ada beberapa nama Para astronom dan astrolog cukup dikenal pada masanya seperti, Al-Khawarizmi, Musa Ibrahim Al-Fazari, AlFarghani/Al farghanus, Al-Battani dan yang lainnya. ${ }^{1}$ Bisa dibayangkan, betapa ilmu pengetahuan dan teknologi sangat bergairah di dunia Islam pada masa itu.

Masa kejayaan Islam tidak mengenal dikotomi keilmuan, antara sain dan agama. Periode selanjutnya,

\footnotetext{
1 Abdul Latif, Tokoh-tokoh Ilmuwan Islam, (http://alanwarkadugedekuini.blogspot.co.id/, diakses pada 20 Agusutus 2019), h. 1.
}

agama dan sain mengkutup dan sering bersitegang antara keduanya. Hingga puncaknya peristiwa Galileo Galilea muncul. Dominasi gereja pada abad 16 pada semua pengetahuan masyarakat, membuat temuan baru harus berkesesuaian dengan pandangan gereja atau kitab suci. Tesis Galileo yang mengatakan bahwa matahari adalah pusat tata surya (Heliosentris) bertentangan dengan doktrin Gereja yang berpandangan bahwa bumi adalah pusat dari peredaran tata surya (geosentris). Galileo pun harus mendapat hukuman dari gereja karena menentang ajaran gereja ${ }^{2}$.

Dalam dunia Islam, konflik antara Agama dan sain terwakili antara dua kubu yaitu, pertama kelompok pemikiran tradisionalis (orthodox) yang berciri sufistik dan mengembangkan pola pendidikan sufi. Pola pendidikan ini sangat memperhatikan aspek-aspek bathiniyah dan akhlak atau budi pekerti manusia dan cenderung mengabaikan aspek rasionalitas. Kedua

\footnotetext{
2 Untuk lebih jelas bisa di baca Fadrik Aziz Firdausi, Galileo Dikucilkan Gereja Karena Membela Sains, 8 Januari 2019, https://tirto.id/galileo-dikucilkan-gereja-karenamembela-sains-dc $8 \mathrm{v}$
} 
kubu pemikiran rasionalis yang berciri

liberal, terbuka, inovatif dan konstruktif. Corak pemikiran ini menimbulkan pendidikan empiris rasional. Pola pendidikan bentuk ini memperhatikan pendidikan nalar intelektual. ${ }^{3}$

Para kubu ini pernah bersatu padu pada masa kejayaan Islam berlangsung, saling mengisi satu sama lain. Agama dan sain tidak lagi mau membedakan mana yang harus mereka pelajari, yang jelas baik ilmu agama yang bersumber dari wahyu maupun ilmu pengetahuan yang bersumber dari nalar mereka pelajari tanpa ada dikotomi. Keduanya telah betul-betul dijadikan sebagai sarana dalam menggali ilmu, baik ilmu agama maupun ilmu pengetahuan umum. ${ }^{4}$

Periode harmonis antara sain dan agama berlangsung cukup lama, sampai diangkatnya penguasa baru Abbasiyah "al-Mutawakkil" yang bermadzhab sunni melakukan

3 Zuhairini, 2000. Sejarah Pendidikan Islam. Jakarta: Bumi Aksara, hlm. 109

4 Fauzan, 2005. "Menimbang Sisi Positif Perlunya Pembaruan Pendidikan Islam" dalam Sejarah Sosial Pendidikan Islam, ed. Suwito dan Fauzan. Jakarta: Kencana, hlm. 163 pencabutan ijin resmi Mu'tazilah $^{5}$ sebagai aliran resmi kenegaraan yang pernah terjadi pada masa al-Ma'mun. Kondisi tersebut terus berlanjut hingga pola pemikiran mu'tazilah nyaris tidak mendapat tempat dalam sistem pendidikan ${ }^{6}$. Sejak itu masyarakat tidak lagi mau mendalami ilmu-ilmu sains dan filsafat. Pemikiran logis dan ilmiah yang sebelumnya sangat dominan dan banyak melahirkan karya-karya besar, bergeser ke arah berpikir tradisionaltekstual yang banyak dipengaruhi oleh ajaran spiritualitas, takhayyul dan kejumudan. ${ }^{7}$ Artinya, kemunduran Islam sesungguhnya telah dimulai sejak runtuhnya Mu'tazilah, yang kemudian berimplikasi pada sistem

\footnotetext{
5 Pembahasan mengenai pengaruh pemikiran Mu'tazilah sebagai paham resmi negara yang dicabut pada masa al-Mutawakkil lihat Majid Fakhry, 2002. Sejarah Filsafat Islam Sebuah Peta Kronologis, ter. Zaimul Am. Bandung: Mizan. hlm. 24.

6 Penolakan terhadap Mu'tazilah atau kelompok rasional lebih didasari oleh adanya kepntingan politik, yaitu upaya paksa yang pernah dilakukan penguasa menggiring umat Islam menganut satu ajaran resmi kenegaraan. Antipati ini juga telah menyebabkan pengawasan yang ketat terhadap penerapan kurikulum di Madrasah. Jatuhnya paham Mu'tazilah telah mengangkat kaum konservatif menjadi kuat. Dalam rangka mengembalikanpaham ahlussunnah sekaligus memperkokoh basis para ulama sering melakukan kontrol terhadap kurikulum di lembaga-lembaga pendidikan. Pada masa ini, materi pelajaran sangat minim, hanya terbatas pada ilmu-ilmu agama, bahkan pendidikan Islam lebih identik dengan pengajaran tasawuf dan fiqih. Lihat Fauzan, "Menimbang Sisi Positif, hlm. 163-164

7 Hanun Asrahah, 1999. Sejarah Pendidikan Islam. Jakarta: Logos. hlm. 123
} 
pendidikan Islam pada umumnya yang mengisolasi dari dari dunia kreatifitas dan nalar kritis.

Pertikaian dua kubu ini semakin memperkuat pola pendidikan tradisional yang lebih menekankan pendidikan tasawwuf dan fiqh dan kurang menekankan pendidikan nalar kritis. Polarisasi agama dan sain tersebut terasa hingga sekarang. Perkembangan pendidikan Islam semakin jumud. Kreasi-kreasi dan budaya baru yang lazim diproduksi dalam dunia pendidikan tidak lagi nampak terlihat. Dunia pendidikan tidak lebih hanya mengulang-ulang (repetitif) produk lama. Kondisi semacam menyebabkan ketidakmampuan mengatasi persoalan persoalan baru yang dihadapi sebagai akibat perubahan dan perkembangan zaman. Ketidak mampuan intelektual tersebut, terealisasi dalam pernyataan bahwa pintu ijtihad tertutup. Jiwa taklid dan fanatik madzhab menguasai pemikiran para ulama, sehingga terjadilah kebekuan intelektual secara total. 8

Residu dari kekalahan kaum rasionalis terhadap kelompok pemikiran tradisionalis-tektualis, terasa hingga sekarang. Pendidikan yang lebih menekankan nalar kritis tertatih tatih untuk bangkit kembali dan sulit mendapatkan tempat dalam sistem pendidikan Islam. 'Pertikaian' antara kaum tradisionalis dan rasionalis terus berlangsung hingga sekarang. Padahal, keduanya sangat dibutuhkan dalam membangun peradaban kokoh. 'Faksi' tradisional sangan konsen dalam spiritualitas, sedangkan faksi rasional sangat kuat dalam pengembangan nalar kritis inovatif.

Demikian juga kampuskampus di tanah air yang semakin 'hijau'. Marak dengan berbagai kegiatan kegamaan. Bahkan kampus umum juga ikut-ikut merekrut para hafids untuk bergabung di dalamnya. Kampus-kampus yang kental dengan kajian sain dan teknologi juga semakin rajin pengajian agama.

\footnotetext{
8 Zuhairini, Sejarah Pendidikan, hlm. 111.
} 
Dengan kondisi yang demikian, rasanya kampus-kampus yang menggaungkan integrasi keilmuan, akan banyak mendapatkan kendala, yaitu akan banyak terperangkap dalam sakralitas teks-teks agama yang 'haram' untuk dibongkar. Masyarakat akademis tanah air bergerak semakin ke arah formalisme ${ }^{9}$ ketimbang subtansialisme agama. Gejala yang demikian sangat nampak terlihat dalam kegiatan dunia kampus. Dunia akademik lebih marak tabligh akbar10 yang monolog, ketimbang memproduksi ilmu pengetahuan dan teknologi dari hasil riset serius dan panjang.

Bila ditelisik lebih jauh, dikotomi keilmuan dalam kontek Indonesia adalah produk dari kolonialisme sekaligus produk politik pendidikan itu sendiri. Kewenangan masingmasing lembaga dalam mendirikan dan mengelola pendidikan, adalah

9 Lebih jelas bisa disimak wawancara Frans Magnis Suseno dalam https://www.dw.com/id/romo-magnispendidikan-budaya-di-indonesia-dihabisi-olehformalisme-agama/a-40840690

10 Tablikh akbar adalah semacam ceramah monolog yang menghadirkan massa yang besar dengan menghadirkan penceramah tokoh-tokoh agama yang sudah terkenal. Dalam kampus umumnya mengkerahkan para dosen dan mahasiswa. Tradisi ini kurang tepat, mengingat tradisi kampus adalah dialok bukan monolog, yang menempatkan penceramah sebagai kebenaran tunggal. awal dari ter-sekat-sekatnya ilmu pengetahuan. Kementrian agama yang diberi kewenangan mengelola pendidikan, tentu tidak bisa keluar dari wilayah keagamaan. Pendidikan agama, memang 'kapling' dari kementrian agama. Pendidikan model apapun yang dikembangkan oleh kementrian agama, tidak bisa jauhjauh dari wilayah keagamaan, yang dimaknai oleh para pemerhati pendidikan sebagai kajian keislaman yang sempit. Parahnya lagi, justru kajian keagamaan di lingkungan PTKIN mengalami penurunan. Seperti yang dikatakan oleh menteri agama Fahrur Razi pada suatu acara di aula HM Rasjidi, Thamrin Jakarta pada 20 Desembe 2019. Dengan mengatakan " Kajian keislaman di kampus Perguruan Tinggi Keagamaan Islam Negeri (PTKIN) berkembang pesat pada tahun 1980-an. Namun sayang, tradisi keilmuan tersebut kini dirasakan mulai meredup"11.

Dua kegelisahan Imam
Suprayogo yaitu dikotomi sempit dan ketertinggalan pendidikan dan ilmu $11 \quad$ https://www.medcom.id/pendidikan/news-
pendidikan/9K5rl6aN-peminat-bidang-kajian-keislamandi-ptkin-terus-menurun? 
pengetahuan di semua level, membuatnya bersemangat mencari akar persoalan, dan dikotomi keilmuan salah satu tertuduh, sebagi biang ketertinggala Islam dalam bidang sain. Dikotomi ilmu penegetahuan yang selama ini dianut dalam sistem pendidikan tinggi di Indonesia, menempatkan perguruan tinggi Islam hanya berkutat pada kajian keilmuan yang sempit. ${ }^{12}$

\section{Metode Penelitian}

Paper ini disusun menggunakan metode telaah pustaka, dengan cara mengutip pendapat dari berbagai tulisan yang telah dibaca, kemudian ditelaah dan dianalisis sesuai dengan kemampuan penulis yang bergiat di dunia pendidikan. Untuk pengumpulan data pada makalah ini digunakan metode pengumpulan data literer, yakni dengan terlebih dahulu menelusuri buku-buku yang ada relevansinya dengan masalah-masalah yang dibahas dan melalui jaringan internet untuk dikaji guna mencari landasan upaya pemecahan persoalan

12 Imam Suprayogo, 2016. Membangun Itegrasi Ilmu Dan Agama : Pengalaman UIN Maulana Malik Ibrahim Malang, Makalah ini disampaikan pada kegiatan seminar di IAIN Batu Sangkar pada tanggal 15 Oktober 2016

\section{Pembahasan}

\section{Integrasi yang Rumit}

Secara teoritik integrasi antara sain dan agama memang kelihatanya sederhana. Namun dalam praksis hingga memasuki 17 tahun tandatanda akan munculnya produk 'sain teknologi Islam' sebagaimana yang diharapkan belum juga nampak. UIN masih sibuk dengan kajian dan wacana keagamaan 'klasik' sedia kala.

Beberapa ahli melihat terdapat kerumitan mengintegrasikan antara Agama (Islam) dan sain teknologi. Diantara Ronald lukens Bull yang mengatakan:

One major way in which the "where is the Islam?" question is addressed is through defining and redefining different approaches to the relationship between science and religion. As we saw in chapter 3, there have been a number of different approaches. A very popular one takes a proof-texting approach and tries to find Quranic verses and Hadith that support the findings and theory of science. This does not seem promising to me, such prooftexting of science leads to a crippled science because all 
find- ings must be verified in the holy text; science, by definition, must be open to discovery, verification, and falsification. It also leads to bad hermeneutics because it approaches the text with an intended outcome instead of reading the text and seeing where it leads ${ }^{13}$.

(salah satu cara yang mempertanyakan dimanakah islamnya dapat diutarakan melalui pendefinisian ulang pendekatan yang berbeda terhadap pendekatan agama dan keilmuan. Seperti yang kita lihat dalam bab III, terdapat pendekatan yang berbeda salah satunya yang sangat populer menggunakan pendekatan pembuktian yang tertulis dan mencoba menemukan ayatayat al quran dan hadit yang mendukung penemuan dan teori keilmuan. Hal ini tidak nampak menjanjikan bagi saya, karena pembuktian tertulis semacam itu pada ilmu yang pincang, karena seluruh penemuanya harus di verifikasi dengan kitab suci. Sain secara secara defini harus terbuka terhadap nemuan, verifikasi dan penyangkalan. Hal ini bisa mengarah pada hal yang buruk

${ }^{13}$ Robald Luken Bull, 2013. Islamic Higher Education in Indonesia: Contiunity and conflic Pilgrave Mc Millan, USA. Hal 114 karena alih-alih membaca teks dan kemana ia akan menuju. Ia melakukan pendekatan terhadap teks tersebut dengan hasil yang sudah ditentukan.

Bisa dibayangkan, perkembangan ilmu dan teknologi yang demikian pesat, harus di verifikasi dengan kitab suci yang sakral dan mutlak kebenarnya. Yang akan mungkin terjadi adalah pemaksaan dan 'cocokologi'. "Semua sudah ada di kitab suci, kitab suci sudah membahas sejak dulu, 15 abad yang lalu, ilmu ini, ilmu itu sesuai dan tidak sesusi dengan kitab suci", dan kalimat sejenis adalah klaim klaim yang akan sering didengar pada model keilmuan integarasi sain dan kitab suci. Belum lagi kitab suci yang sakral yang tidak bisa dikritik, akan banyak mempersulit 'perjodohan' ilmu dan sain yang banyak diidealkan oleh para cendikiawan muslim.

Bahkan Hasan Hanafi malah menyarankan tidak menjadikan al Qur an sebagai isu utama dari berbagai wacana yang muncul, terutama dalam berbagai kajian 
keilmuan. Seperti yang dikutip Najib Burhani:

Hasan Hanafi bahkan menganggap Al-Qur'an itu bukan isu yang perlu diperbincangkan sama sekali dalam masalah ini. Hanafi pernah mengatakan bahwa AlQur`an itu seperti -supermarket. Orang bisa datang dan kemudian mengambil apa yang ia butuhkan dan mengacuhkan apa yang tak diperlukan (Kersten 2011, xiii). Dalam kaitannya dengan Al-Qur'an, Hanafi menyebutkan bahwa kitab suci ini akan mengikut saja kepada orang yang menafsirkan dan menampilkannya (Boullata 1990, 41). Pemikiran Hanafi itu akan terasa sangat ideologis, atau lebih tepatnya ke arah kiri Islam' atau Marxisme. Serupa dengan pandangannya tentang Al-Qur'an, ia juga tak terlalu mempermasalahkan khazanah Islam klasik senyampang itu bisa dimanfaatkan sebagai perangkat ${ }^{14}$

Al Qur an dan Hadits sebagai teks terbuka bisa ditafsirkan sesuai dengan berbagai kepentinga para

14. Ahmad Najib Burhani, 2014. Kitab Kuning dan Kitab Suci: Membaca 'Abid al-Jabiri dengan Perspektif NU dan Muhammadiyah. Naskah AICIS penafsirnya, terkait dengan kemampuan, soio-budaya dan latar akademiknya. Maka menjadikan Al Qur'an dan Hadits sebagai sumber dari segala sumber keilmuan, cenderung hanya dipaksakan. Karena realistasnya, kajian keilmuan yang muncul, lahir dari hasil pemikiran mendalam dan pergulatan di lapangan, tidak membaca dari kitab suci terlebih dahulu.

Berbagai ragam keilmuan yang bermunculan, justru tumbuh subur dari tradisi berfikir dan meneliti yang sangat liberal, tidak dari tradisi pembacaan kitab suci. Maka kitab suci harus diletakkan sebagai sumber moral tertinggi, sebagai cita-cita masyarakat yang beradab. Sebagaimana model keilmuan Tabot, yang menempatkan kitab suci (al Quran, hadits dan kebangsaan) dalam poisisi atap. Maka kitab suci tidak akan kehilangan ruh dan wibawanya sebagai pengayom dan petunjuk alam raya dan pengikutnya.

Bila menilik sejarah, sain yang berkembang pesat di barat realitasnya dibangun atas dasar semangat kebebasan dan penentangan terhadap 
doktrin ajaran agama (kristen) yang kaku. Misi yang paling mencolok yang disisipkan ke dalam sains barat adalah sekulerisasi. ${ }^{15} \quad$ Sekulerisasi sendiri mempunyai pengertian yaitu, menunjukkan setiap proses sosial dan historis yang membawa perubahan yaitu semakin mengesampingkan kepercayaan dan nilai-nilai religius dan menjelaskan segala sesuatu melulu dalam lingkup dunia. ${ }^{16}$ Suasana kebebasan demikian membekas bagi para ilmuan tanah air yang baru pulang belajar dari barat untuk bisa dikembangkan di Indonesia.

Kerumitan Integrasi Keilmuan UIN

\begin{tabular}{|c|c|}
\hline $\begin{array}{l}\text { Jenis } \\
\text { Kerumitan }\end{array}$ & Keterangan \\
\hline $\begin{array}{l}\text { Potensi klaim } \\
\text { sepihak }\end{array}$ & 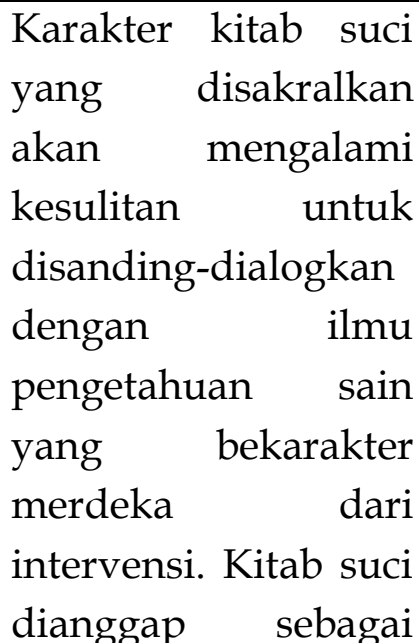 \\
\hline
\end{tabular}

${ }^{15}$ Mujamil Qamar, Epistimologi Pendidikan Islam Dari Metode Rasional Hingga Metode Kritik, (Jakarta : Erlangga, 2005), h.115.

16 Gerald O'Collins, Kamus Teologi, (Yogyakarta : Kanisius, 1991), h.291

\begin{tabular}{|c|c|}
\hline & $\begin{array}{l}\text { sumber dari segala } \\
\text { sumber ilmu, yang } \\
\text { segalanya sudah ada } \\
\text { tertera dalam kitab } \\
\text { suci, baik secara } \\
\text { qauliyah, maupun } \\
\text { kauniyah. Temuan } \\
\text { apapun dianggap } \\
\text { hanya "menginduk" } \\
\text { dari kitab suci, tidak } \\
\text { ada kebaruan sama } \\
\text { sekali. }\end{array}$ \\
\hline $\begin{array}{l}\text { Sakralisasi } \\
\text { akut } \\
\text { pemikiran } \\
\text { kegamaan, } \\
\text { taqdis al-afkar } \\
\text { ad-dini }\end{array}$ & 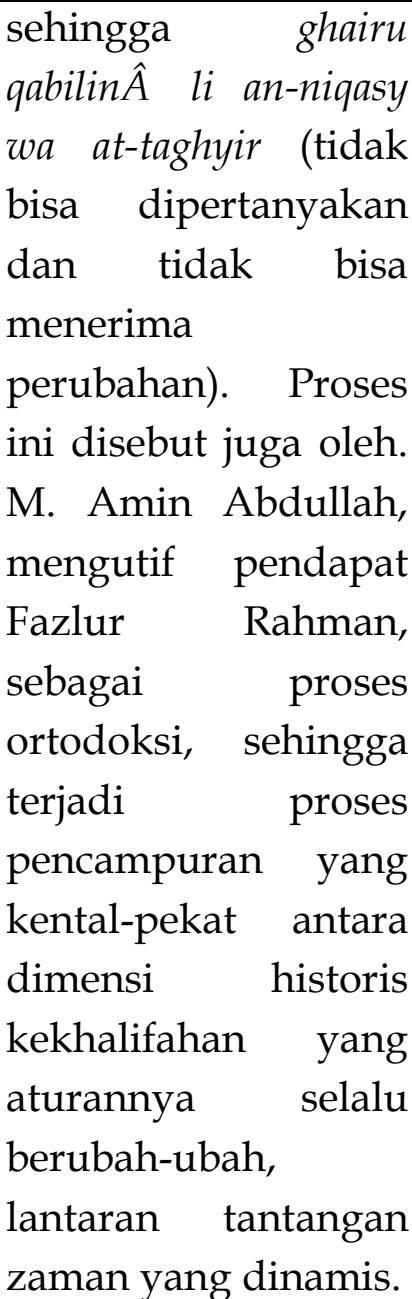 \\
\hline $\begin{array}{l}\text { Ruang } \\
\text { Akademik } \\
\text { yang terbatas }\end{array}$ & $\begin{array}{l}\text { Ada perbedaan } \\
\text { karakter antara studi } \\
\text { agama dan studi } \\
\text { ilmu pengetahuan } \\
\text { umum dan teknologi, }\end{array}$ \\
\hline
\end{tabular}




\begin{tabular}{|c|c|}
\hline & $\begin{array}{l}\text { yaitu itu studi agama } \\
\text { berbasis teks suci } \\
\text { yang sakral, yang } \\
\text { yang berpotensi } \\
\text { menimbulkan gaduh } \\
\text { dalam mengkaji } \\
\text { secara merdeka dan } \\
\text { bebas. Sedangkan } \\
\text { ilmu umum dan } \\
\text { teknologi ruang } \\
\text { mempunyai ran } \\
\text { yang sangat luas, dan } \\
\text { sangat terbuka dalam } \\
\text { 'jual beli' gagasan. } \\
\text { Studi agama } \\
\text { memiliki ruang yang } \\
\text { sangat terbatas dan } \\
\text { rigid, sedangkan } \\
\text { ilmu-ilmu umum } \\
\text { sebaliknya. }\end{array}$ \\
\hline $\begin{array}{l}\text { Keilmuan } \\
\text { yang linier }\end{array}$ & 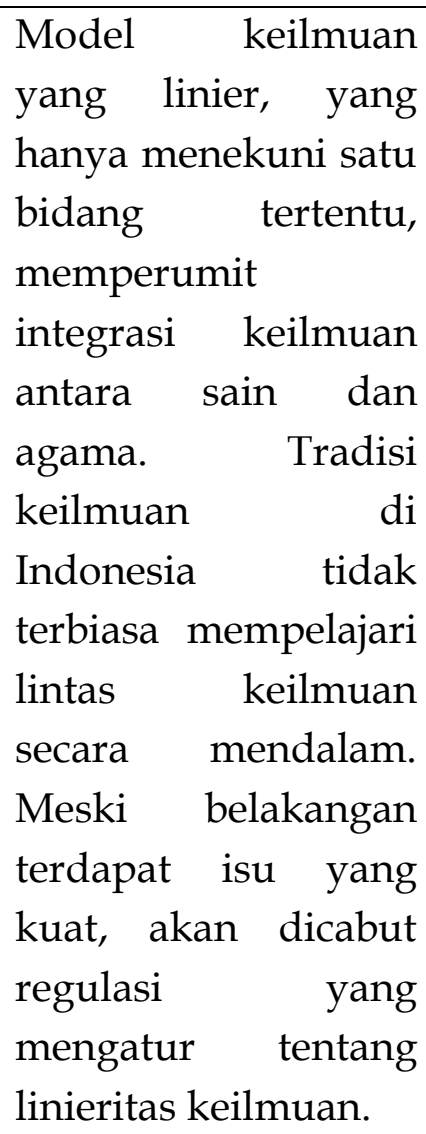 \\
\hline
\end{tabular}

Dengan beberapa kerumitan di atas yang menjadi masalah adalah, jangan-jangan antara sain dan ilmu pengetahuan teknologi, tidak mengalami 'perkawinan' yang harmonis, sebagaimana cita-cita para pemimpi integrasi-interkoneksi, melainkan pertikaian-pertikaian sunyi yang bisa berpotensi terjadi 'perceraian' kembali antara sain dan agama.

Realitas yang terjadi sekarang adalah, setelah wacana integrasiintekoneksi keilmuan berjalan seiring dengan semakin masifnya transformasi IAIN menjadi UIN, hanyalah sebatas interaksi formal antara dua kutub keilmuan tersebut. Bahkan dalam beberapa kasus, 'kubu' agama cenderung melakukan 'pembajakan' sepihak terhadap beberapa produk keilmuan umum. Mata kuliah umum, atau prodi-prodi yang ada di PTKIN.

2. Al-Qur'an dan Sunnah sebagai Supermarket

Konon, abad keemasan Islam terjadi karena para umatnya berpegang teguh pada Al Qur'an dan 
Hadits. Maka untuk kembali pada kejayaan Islam, harus kembali sebagaimana para ilmuan Islam pegang teguh. Abduh misalnya, melihat kemunduran Islam akibat karena singkretisme ajaran Islam yang otentik. Ajaran Islam 'Murni' berkelindan dengan kepercayaan dan tradisi lokal masyarakat. Maka panacea (obat mujarab) yang ditawarkan Abduh adalah 'kembali ke Al Qur'an dan Hadits'17. Abduh

${ }^{17}$ Istilah ini sangat populer dikalangan reformis Islam. Pembahasan seputar ini dibahas dalam Disertasi Yudian Wahyudi (2012) dengan judul. The Slogan 'Back to the Al qur an and Sunna' a Comparative study of the responses Hasan hanafi, Muhammad al jabiri and Nurcholis Madjid. Disertation (Canada Mcgill University Montreal) yaitu dengan memperbandingan para pemikir Islam terkemuka Hasan Hanafi, Al jabiri dan Nurcholis Madjid. Tahun 2010 Yudian juga meneliti tema yang sama di tiga negara yaitu Maroko, Mesir dan Indonesia. Lihat Yudian Wahyudi, 2010. Dinamika Politik Kembali ke Al Quran dan Assunah di Mesir, Maroko dan Indonesia. Pesantren Nawasea, jogja. Lebih lanjut Menurut Yudian, Bahwa pemikiran keIslaman tidak pernah terlepas dari dinamika politik kebangsaan. Gerakan Islam Wahhabi untuk kembali ke Qur'an dan Sunah yang dipelopori Ibn 'Abd al-Wahhab, yang kemudian direspon oleh tokoh-tokoh seperti Muhammad 'Ali Pasha, Al-Afghani, Muhammad 'bduh, Muhammad Rashid Rida, Hasan al-Banna, Sayyid Qutb (Mesir), Sultan 'Abd Allah, Sultan Hasan I, Sultan 'Abd alAziz, Sultan 'Abd al-Hafiz, Al-Dukkali, Allah al-Fasi (Maroko), Garakan Paderi, Sayyid 'Uthman, KH. Ahmad Dahlan, Ahmad al-Shurkati, Ahmad Hassan, Kartosuwirjo (Indonesia) membuktikan, ketika pemikiran kembali kepada Al Qur'an dan Sunnah dipahami secara tekstual/harafiah/literal, tidak pernah bisa membawa kemajuan/kejayaan Islam dan justru selalu memicu konfik dengan penguasa negara. Upaya menuju kekuasaan juga tidak pernah sampai, karena pemahaman secara tekstual membuat umat Islam tidak berdaya, tidak memiliki kekayaan keilmuan apalagi teknologi. Hanya memiliki ilmu tentang tafsir Qur'an dan Sunnah yang sempit dan ketinggalan jaman karena tidak kontekstual dengan peradaban yang semakin maju. Umat Islam hanya bisa menempati posisi sebagai kaum pinggiran yang memimpikan kekuasaan dan tidak pernah tercapai. Tidak bisa menempati posisi-posisi strategi untuk turut serta memajukan bangsa dan negaranya dimana tinggal, karena keilmuan yang tertingal jauh dari kemajuan peradaban. mempercayai bahwa hanya kembali

hanya kembali ke al Qur'an dan Hadits, Islam akan mendapatkan

kejayaanya kembali.

Lebih lanjut, upaya untuk merehabilitasi kondisi umat Islam hanya bisa dicapai dengan cara kembali kepada ajaran Islam yang otentik, yakni ajaran yang pernah membawa umat Islam pada kejayaan, dan membuang semua warisan dari zaman kemunduran. Dalam proyek reformasinya, Abduh mendengungkan slogan "kembali ke al-Qur'an" dan menekankan perlunya sikap kritis terhadap ajaran Islam ortodoks ${ }^{18}$. Sikap kritis Abduh terhadap khazanah Islam ini banyak dipengaruhi oleh gurunya,

\footnotetext{
“Jadi gerakan kembali kepada Al Qur'an dan Sunnah yang dipelopori Wahhabi adalah gerakan kekalahan. Kembali kepada Al Qur'an dan Sunnah jangan hanya menghasilkan harapan yang hampa. Tetapi membawa umat Muslim untuk berpikir kritis agar bisa berharap dari pinggiran menjadi berperan penting bagi kemajuan peradaban bangsa dan negara, bahkan dunia. Dicontohkan dalam pembahasan buku ini bahwa, resonansi pemikiran Ibn. Abd. Wahhab yang begitu luas. Yang membawa harapan hampa maupun yang menghasilkan kemajuan umat Islam. Di Indonesia misalnya; gerakan Paderi mengkitik kaum adat, dibalik itu ada kekuasaan yang akan diambil. Kartosuwiryo menterjemahkan pemikiran Wahhabi untuk memberontak negara, dan tidak membuahkan hasil apa-apa. Ahmad Dahlan yang dari pinggiran merespon dengan menterjemahkan gerakan yang bernuansa intelektual hingga bisa membawa Muhammadiyah berperan penting dalam memajukan bangsa dan negara.

18 Lihat Haddad, Yvonne. 2005. Muhammad Abduh: Pioneer of Islam Reform. Dalam Pioneers of Islamic revival, ed. ' Ali Rahnama, 30-63. New York: Zed Books.
} 
Jamaluddin al-Afghani, yang terkenal dengan sikap penolakannya yang sangat keras terhadap kebiasaan umat Islam dalam membela tradisi Islam klasik secara buta. Sikap Abduh dalam mereformasi Islam ortodoks dengan cara menghidupkan kembali ajaran Islam otentik dan interpretasi langsung terhadap Al-Qur'an ini membuatnya terkenal sebagai modernis atau revivalis Muslim ${ }^{19}$. Secara ringkas, pembaruan versi 'Abduh ini terpusat pada dua aktivitas: sikap kritis terhadap tradisi dan penggunakan akal untuk memahami Al-Qur'an secara langsung. ${ }^{20} \quad$ Strategi untuk menemukan Islam otentik sering diterjemahkan dalam program seperti penciptaan masyarakat eksklusif dan membentuk enclave dengan menjadikan periode awal Islam sebagai prototipe atau paradigmanya. Cara ini dianggap bisa menjadi satu-satunya 'remedy for all ills' (obat

19 Charles Kurzman. 2002a. Introduction to _Laws should change in accordance with the conditions of nations' and the theology of unity, by Muhammad 'Abduh. Dalam Modernist Islam: a sourcebook, 1840-1940, ed. Charles Kursman. New York: Oxford University Press. hal 50

20 Ahmad Najib Burhani, 2014. Kitab Kuning dan Kitab Suci: Membaca `Abid al-Jabiri dengan Perspektif NU dan Muhammadiyah. Naskah AICIS. dari semua penyakit) yang saat ini menjangkiti umat Islam ${ }^{21}$.

Masalah muncul kemudian adalah, gerakan kembali ke al Qur'an dan Hadits tidak berjalan sebagaimana yang diharapkan. Yaitu, mengembalikan ajaran islam pada sumber utamanya, yang mengakaji kitab suci dengan sungguh sungguh. Melainkan lebih kental gerakan politik ${ }^{22}$-tekstualis. Kitab suci sebatas menjadi barang 'dagangan' dan ditafsir secara literer semata untuk kekuasaan.

Doktrin kembali ke al Qur'an dan haditss ${ }^{23}$, nampak dominan dalam desain keilmuan yang banyak ditawarkan oleh perguruan tinggi Islam yang baru memperoleh status baru menjadi UIN. Mulai dari UIN Syarif Jakarta, UIN Suka Jogja, UIN Maliki Malang, UIN Bandung (roda ilmu) dan bahkan UIN Ampel Surabaya. Semua menjadikan kitab suci sebagai sumber dari segala

\footnotetext{
21 Sayeed, S. M. A. 1995. The myth of authenticity: a study in Islamic fundamentalism. Karachi: Royal Book Co. P 270

22 Lebih jelas lihat Yudian Wahyudi, 2010. Dinamika Politik Kembali ke Al Quran dan Assunah di Mesir, Maroko dan Indonesia. Pesantren Nawasea, jogja

${ }^{23}$ Ulasan lebih lengkap bisa dilihat Pradana Boy ZTF dan M Hilmi Faiq (eds.). 2004. Kembali ke Al-Qur"an, menafsir makna zaman. Malang: UMM Press
} 
sumber ilmu pengetahuan di masing masing lembaga tinggi Islam yang baru lahir.

Apalagi kampus yang akan memfokuskan pada dua rumpun keilmuan sekaligus, yaitu agama dan sain, yang keduanya memiliki kompleksitas sendiri sendiri. Tentu dibutuhkan ekstra energi untuk bisa mewujudkannya. Sebagaimana Ziauddin Sardar yang pesimis akan kemampuan para ilmuwan muslim untuk memadukan ilmu Islam dengan ilmu Barat karena di antara keduanya terdapat perbedan paradigma yang mencolok ${ }^{24}$. Juga kompleksitas masingmasing rumpun ilmu tersebut.

3. Peminat Meningkat, Studi Kental Keislaman Menurun

Sebenarnya bukan fenomena baru bila studi yang kental dengan kajian keagamaan sudah lama 'sekarat'. Peminat prodi semacam Ilmu Hadit, Filsafat Agama, Ilmu Qur'an dan tafsir serta prodi sejenis sangat minim peminat. Kondisi sebaliknya terjadi pada prodi prodi yang lebih

\footnotetext{
24 Wirna Khusnul Urifah. 2010. Konsep Islamisasi Ilmu Pengetahuan menurut Syed Naquib al-Attas dan Ismail Raji al-Faruqi (Studi Perbandingan). Skripsi Jurusan Pendidikan Agama Islam Fakultas Tarbiyah IAIN Sunan Ampel Surabaya. Hal 83
}

'umum', karena kajian keagamaanya lebih ringan seperti Prodi Perbankan Syariah, Ekonomi Syariah, Pendidikan Agama Islam dan sebagainya.

Berikut beberapa prodi yang paling diminati dalam SPAN-PTKIN tahun 2018.

a. Perbankan Syariah UIN Syarif Hidayatullah Jakarta diminati 11.326 pendaftar dan hanya menerima 56 calon mahasiswa

b. Perbankan Syariah UIN Sunan Kalijaga Yogyakarta diminati 10.523 pendaftar dan cuma menerima 60 calon mahasiswa

c. Ekonomi Syariah UIN Syarif Hidayatullah Jakarta diminati 9.618 pendaftar dan hanya menerima 55 calon mahasiswa

d. Perbankan Syariah UIN Maulana Malik Ibrahim Malang diminati 9.151 pendaftar dan menerima 85 calon mahasiswa

e. Manajemen Keuangan Syariah UIN Sunan Gunung Djati Bandung diminati 8.625 pendaftar dan dan hanya menerima 92 calon mahasiswa.

Fenomena ini boleh jadi terjadi di semua PTKIN. Baik yang berbentuk 
STAIN, IAIN maupun UIN. IAIN

Bengkulu juga demikian, prodi Perbankan Syariah, Ekonomi Syariah, Pendidikan Agama Islam (PAI), Pendidikan Guru Madrasah Ibtidaiyah (PGMI), selalu diserbu peminat. sudah ada jauh sebelum wacana integrasi keilmuan

Peningkatan minat calon mahasiwa ke PTKIN:

Tahun 2015 - 101.787

Tahun 2016 - 129.327

Tahun 2017 - 157.039

Tahun 2018 - 218.449

Tingginya minat terhadap PTKIN tentu berita menggembirakan. Peningkatan secara tajam terjadi pada tahun 2018. Paling tidak, PTKIN yang dulunya hanya dianggap sebagai 'penggembira' dalam kontestasi perguruan tinggi nasional, sekarang bisa menegakkan kepala, dengan tingginya minat ke PTKIN. Meski harus diakui, masih banyak yang harus dikejar, untuk bisa sejajar dengan PT di dunia lainnya. Meningkatnya pasar PTKIN ternyata tidak diiringi dengan meningkatnya kajian keislamam yang kuat. Paling tidak hal tersebut dikemukakan oleh
Mantan Menteri Lukman Saifuddin serta menteri Agama sekarang Fakhrus Razi, mengungkapkan hal senada, tentang keprihatnya tentang menurunya kajian keislaman yang kuat.

Sebagainya implikasinya, integrasi keilmuan antara sain dan Agama tentu akan mendapat kendala, karena pihak agama sendiri mempunyai persoalan sendiri dan tidak siap untuk 'dikawinkan' dengan sain yang jauh lebih mapan. Statmen menteri agama harus menjadi perhatian penting, bila masih ingin nilai-nilai agama menjadi ruh dari pesatnya perkembangan teknologi.

Kekhawatiran yang paling mendasar adalah, proyek UINisasi hanyalah sekedar berebut pasar 'konvensional' PTN dengan kemasan baru yang lebih syar'i, yaitu yang bernama UIN. Juga semakin memberi 'panggung' bagi keilmuan umum dalam lingkungan PTKIN. Pada akhirnya, studi yang kental keislaman akan semakin tersudut dalam ruang yang sempit, tergilas oleh maraknya keilmuan umum, sebagaimana yang terjadi di Universitas Islam yang sudah 
ada.

4. Keilmuan Tabot: Terbuka beratapkan Al Qur'an, Hadits dan Kebangsaan

Paling tidak ada beberapa pertimbangan perlunya kitab suci disandingkan dengan dengan nilainilai luhur kebangsaan:

a. Kitab Suci sebagai teks terbuka rentan terjangkit ideologi asing yang tidak sesuai dengan islam Indonesia yang wasthiyah (moderat) $^{25}$.

b. Gerakan kembali ke Al Qur'an dan $\mathrm{Al}$ hadits (termasuk dalam desain keilmuan) rentan terinveksi virus politisasi yang hanya menjauhkan dari nilai-nilai Islam itu sendiri. Sebagimana penelitian Yudian Wahyudi tentang gerakan kembali ke $\mathrm{Al}$ Qur an dan Sunah di Mesir, Maroko dan Indonesia ${ }^{26}$.

\footnotetext{
25 Disampaikan Azyumardi Azra dalam“ Overview Penguatan Bangunan Epistemologi Keilmuan dan Integrasi Ilmu Islam dan Sains." FGD yang berlangsung di Jakarta, 22-23 September 2019

${ }^{26}$ Lebih lengkap bisa dilihat dalam hasil penelitian Yudian Wahyudi, 2010. Dinamika Politik Kembali ke Al Quran dan Assunah di Mesir, Maroko dan Indonesia. Pesantren Nawasea, Jogjakarta, yang mengatakan bahwa gerakan kembali ke Al Qur'an dan Sunah kental dengan motif politik kekuasaan, yang banyak berujung pada kekalahan.
}

c. Kepentingan kebangsaan sama pentingnya dengan kepentingan keagamaan. Karena hanya dalam kondisi negara yang damai, citacita agama dapat diwujudkan dengan baik.

Sehingga kitab suci, perlu disanding-integrasikan dengan nilainilai luhur budaya lokal. Spirit islam yang rahmatan lil aalaminn menjadi lebih membumi di mana pun berada dan tidak mengisolir diri budaya setempat yang sudah berurat akar.

Dengan penjelasan tersebut, UIN baru harus memasuki tahapan post-integrasi karena pada dasarnya sudah sejak lama dipraktekkan dalam lembaga pendidikan Islam sejak lama dan Islam pada dasarnya tidak mengenal dikotomi keilmuan. Yang diperlukan adalah hilirisasi atau pembumian keilmuan yang berwawasan kebangsaan.

Secara sederhana, domestifikasi (pembumian) keilmuan lebih pada pengejawantahan dalam karya dan prilaku sehari-hari. Misalnya untuk membumikan nilai-nilai, kampus kampus Islam, terutama yang dalam lingkungan PTKIN, kebersihan dan 
kerapian harus menjadi pemandangan Gambar Desain Keilmuan Tabot

utama. Dari mulai sektor depan hingga sektor belakang. Kantin, WC, tempat parkir, ruang kelas, ruang dosen dan yang lainnya, bersih dan rapi yang tidak kalah dengan kampuskampus terkemuka di Eropa.

Dalam pergaulan akademik juga demikian, toleransi dan menjunjung tinggi etika pergaulan menjadi pemandangan dalam lingkungan di PTKIN. Produktifitas keilmuan yang tinggi ditopang dengan lingkungan akademik yang kondusif menjadi karakteristik kampus kampus PTKIN yang tersebar di seluruh pelosok tanah air.

Artinya, kajian keislaman dan keilmuan selama ini lebih banyak diteorikan, diceramahkan, melangit dan kurang dibumikan. Demikian pula bidang bidang ilmu yang lebih umum, banyak hasil research yang unggul dan teknologi sederhana tepat guna, lebih banyak yang mangkrak di lab, ketimbang diwujudkan dalam bentuk karya nyata.

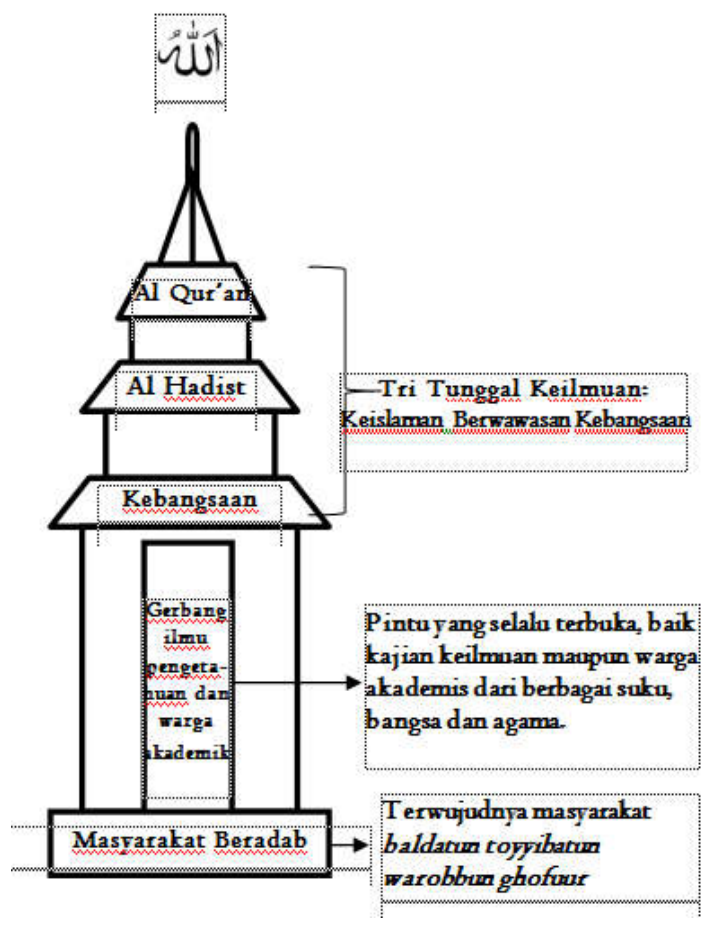

Penutup

Sejatinya agama dan lokalitas kebangsaan seperti dua sisi keping mata uang yang tidak bisa dipisahkan. Agama hadir tidak dalam ruang hampa budaya. Melainkan agama selalu mencakup dua entitas yang tidak dapat dipisahkan tetapi dapat dibedakan, yaitu normativitas dan historitas. Normatifitas adalah seperangkan ajaran agama yang meliputi teks, ajaran, belief, dogma dan juga historisitas adalah praksis pelaksanaan ajaran, teks, belief, dogma tersebut dalam kehidupan di lapangan. 
Realitas sendiri juga terikat dengan setting budaya masing masing. Budaya dan agama selalu menjadi rujukan dalam bertidak dan berprilaku di masyarakat. Bedanya agama diangap sakral dan mutlak karena kehadiranya diyakini berasal dari Tuhan. Sedangkan budaya bersifat profan, karena hasil dari kesepakatan manusia.

Sebelum kedatangan agama, masyarakat terlebih dahulu mempunyai norma-norma dan budaya yang diikuti, dipatuhi sebagai pedoman dalam bermasyarakat. Hingga suatu ketika datanglah agama (islam), yang akan membawa 'sesuatu' yang serupa dengan pedoman berprilaku dalam masyarakat. Maka dialog tidak bisa dihindarkan antra sesuatu yang baru (agama) dengan sesuatu yang lama (budaya yang sudah berurat akar di masyarakat).

Dialog agama-budaya yang paling bisa menjadi contoh sukses adalah pada masa Wali Songo. Kedatangan Islam di Jawa nyaris tanpa resistensi dan gejolak. Bahkan dalam banyak hal, malah disambut dengan terbuka kehadirannya. Tidak mudah membawa sesuatu yang baru, apalagi terkait dengan budaya, yang akan menjadi tuntunan berprilaku di masyarakat, akan mendapat persoalan bila tidak tepat dalam berinteraksi.

Semacam dakwah domestifikasi yang dilakukan oleh Wali Songo, yaitu penyesuaian diri terhadap budaya lokal, sehingga kedatanganya tidak dianggap lain dari yang selama ini dijalankan. agama disesuaikan dengan konteks masyarakat lokal. Agama akan mudah diterima masyarakat apabila ajaran agama tersebut memiliki kesamaan dengan kebudayaan masyarakat, sebaliknya agama akan sulit diterima masyarakat bila berjarak dengan budaya masyarakat setempat.

Budaya asing, termasuk agama dan keyakinan harus didialogkan dengan budaya lokal. Sebagai 'tuan rumah', budaya lokal harus mendapat tempat yang terhormat diantara lalu lalang budaya dan keyakinan yang datang. Dalam istilah Mujiburrahman, Islam harus dinusantarakan atau mengindonesiakan Islam. ${ }^{27}$

27 Mujiburrahman, 2008, Mengindonesiakan Islam, Pustaka Pelajar: Jogjakarta. 


\section{Referensi}

1. Abdul Latif, 2019. Tokoh-tokoh Ilmuwan Islam, (http://alanwarkadugedekuini.blogspot.co.id/, diakses pada 20 Agusutus 2019

2. Ahmad Najib Burhani, 2014. Kitab Kuning dan Kitab Suci: Membaca 'Abid al-Jabiri dengan Perspektif NU dan Muhammadiyah. Naskah AICIS

3. Azyumardi Azra. 1999. Esei-esei Intelektual Muslim dan Pendidikan Islam. Jakarta: Logos.

4. Boy ZTF, Pradana dan M Hilmi Faiq (eds.). 2004. Kembali ke Al-Qurean, menafsir makna zaman. Malang: UMM Press

5. Charles Kurzman (Ed.), 1988. Liberal Islam A Sourcebook, New York:Oxford University Press.

6. Dahri, Harapandi, 2009. Tabot (Jejak Cinta Keluarga Nabi di Bengkulu), Jakarta: Pemikat Citra.

7. Durkheim, Emile. 2011. The Elementary Form of The Religious Life, Sejarah Bentuk-Bentuk Agama yang Paling Dasar, Terj : Inyiak Ridwan Muzir dan M.Syukri, Jogjakarta : IRCiSoD, 2011

8. Fadrik Aziz Firdausi. 2019. Galileo Dikucilkan Gereja Karena Membela Sains, 8 Januari 2019, https:// tirto.id/galileo-dikucilkangereja-karena-membela-sains-dc8v

9. Fauzan. 2005. "Menimbang Sisi Positif Perlunya Pembaruan Pendidikan Islam" dalam Sejarah Sosial Pendidikan Islam, ed. Suwito dan Fauzan. Jakarta: Kencana.

10. Frans Magnis Suseno dalam https://www.dw.com/id/romomagnis-pendidikan-budaya-diindonesia-dihabisi-oleh-formalismeagama/a-40840690

11. Imam Suprayogo, 2016. Membangun Itegrasi Ilmu Dan Agama : Pengalaman UIN Maulana Malik Ibrahim Malang, Makalah ini disampaikan pada kegiatan seminar di
IAIN Batu Sangkar pada tanggal 15 Oktober 2016

12. Ismail al-Frauqi, 1994. Dialog Tiga Agama Besar, Surabaya: Pustaka Progressif,

13. M Amin Abdullah, 2006. Islamic Studies di Perguruan Tinggi: Pendekatan Integratif-Interkonektif. Yogyakarta: Pustaka Pelajar.

14. -- 2005. "Desain Pengembangan Akademik IAIN menuju UIN Sunan Kalijaga", dalam Zainal Abidin Bagir, dkk, editor, Integrasi Ilmu dan Agama Interpretasi dan Aksi. Bandung: Mizan.

15. Mujiburrahman, 2008, Mengindonesiakan Islam, Pustaka Pelajar Jogjakarta.

16. Nana Syaodih, 2009. Pengembangan Kurikulum, Teori dan Praktik, Bandung: Remaja Rosdakarya.

17. Noorhaidi Hasan, 2011. "Islamizing Formal Education: Integrated Islamic School and New Trend in Formal Education Institution in Indonesia" Artikel Online di S. Rajartanam School of International Studies Singapore, Februari 2011.

18. Nur Syam, "Integrative Twin Tower: Arah Islamic Studies Ke Depan", $/ ? \mathrm{p}=1081$, diakses tanggal, 9 Maret 2011

19. Parluhutan Siregar, 2014. Integrasi ilmu-ilmu keislaman dalam perspektif Amin Abdullah, MIQOT Vol. XXXVIII No. 2 Juli-Desember.

20. Robald Luken Bull 2013. Islamic Higher Education in Indonesia: Contiunity and conflic, Pilgrave Mc Millan, USA. Hal 114

21. Sayeed, S. M. A. 1995. The myth of authenticity: a study in Islamic fundamentalism. Karachi: Royal Book Co.

22. Suyatno, 2015. Dekonstruksi Pendidikan Islam Sebagai Subsistem Pendidikan Nasional, Jurnal Pendidikan Islam Volume IV, Nomor 1, Juni 2015, 77 
23. Tanner Daniel \& Tanner Laurel. N., 1980. Curriculum Development, New York: Mac Millan Publishing co., inc.

24. Wirna Khusnul Urifah, 2010. Konsep Islamisasi Ilmu Pengetahuan menurut Syed Naquib al-Attas dan Ismail Raji al-Faruqi (Studi Perbandingan). Skripsi Jurusan Pendidikan Agama Islam Fakultas Tarbiyah IAIN Sunan Ampel Surabaya.

25. Yudian Wahyudi, 2012. The Slogan 'Back to the Al qur an and Sunna' a Comparative study of the responses Hasan hanafi, Muhammad al jabiri and Nurcholis Madjid. Disertation (Canada Mcgill University Montreal )

26. --_-_-_-_-_ 2010. Dinamika

Politik Kembali ke Al Quran dan Assunah di Mesir, Maroko dan Indonesia. Pesantren Nawasea, Jogjakarta 